ARTICLE

Received 12 Aug 2013 | Accepted 21 Oct 2013 | Published 21 Nov $2013 \quad$ DOl: 10.1038/ncomms3802

\title{
Downsizing a human inflammatory protein to a small molecule with equal potency and functionality
}

Robert C. Reid ${ }^{1}$, Mei-Kwan Yau', Ranee Singh¹, Johan K. Hamidon¹, Anthony N. Reed ${ }^{1}$, Peifei Chu', Jacky Y. Suen ${ }^{1}$, Martin J. Stoermer ${ }^{1}$, Jade S. Blakeney ${ }^{1}$, Junxian Lim¹, Jonathan M. Faber ${ }^{1}$ \& David P. Fairlie ${ }^{1}$

A significant challenge in chemistry is to rationally reproduce the functional potency of a protein in a small molecule, which is cheaper to manufacture, non-immunogenic, and also both stable and bioavailable. Synthetic peptides corresponding to small bioactive protein surfaces do not form stable structures in water and do not exhibit the functional potencies of proteins. Here we describe a novel approach to growing small molecules with protein-like potencies from a functionally important amino acid of a protein. A 77-residue human inflammatory protein (complement $\mathrm{C} 3 \mathrm{a}$ ) important in innate immunity is rationally transformed to equipotent small molecules, using peptide surrogates that incorporate a turninducing heterocycle with correctly positioned hydrogen-bond-accepting atoms. Small molecule agonists (molecular weight $<500 \mathrm{Da}$ ) examined for receptor affinity and cellular responses have the same high potencies, functional profile and specificity of action as C3a protein, but greater plasma stability and bioavailability.

\footnotetext{
${ }^{1}$ Division of Chemistry and Structural Biology, Institute for Molecular Bioscience, The University of Queensland, Brisbane, Queensland 4072, Australia. Correspondence and requests for materials should be addressed to D.F. (email: d.fairlie@imb.uq.edu.au).
} 
$\mathrm{P}$ rotein-protein interactions underlie most biological processes defining life, aging, disease and death. However, the use of proteins in science, industry and medicine is still significantly restricted by their high cost of manufacture, chemical instability, immunogenicity and poor bioavailability. The need to overcome these deficiencies has driven many chemical efforts, but it has been extremely challenging to reproduce the exquisitely potent and specific actions of proteins ${ }^{1-6}$. The biological functions of some proteins are localized in very short polypeptide segments stabilized in specific structures (two to four helical turns, isolated $\beta$-turns, strands/sheets, and their combinations) by their protein environments ${ }^{7,8}$. Yet, even in these simpler cases, short synthetic peptides corresponding to bioactive protein components do not display functional potencies comparable to proteins and are not thermodynamically stable structures in water, where they instead adopt random interconverting structures ${ }^{9}$.

An important example of a protein to functionally mimic is the human complement protein C3a. This is a $9 \mathrm{kDa}$ helix bundle that plays key roles in innate immune responses to infection and tissue injury by interacting with a $100 \mathrm{kDa}$ cell surface protein, a G proteincoupled receptor (GPCR) called C3aR ${ }^{10-12}$. C3a is a powerful proinflammatory agent that recruits immune cells to sites of infection (chemotaxis) and induces immune cells to secrete bactericidal agents (via degranulation) as well as inflammatory cytokines ${ }^{33,14}$. Overexpression of $\mathrm{C} 3 \mathrm{a} / \mathrm{C} 3 \mathrm{aR}$ or sustained activation of its receptor can lead to inflammatory diseases, including allergies ${ }^{10}$, asthma ${ }^{15}$, arthritis $^{16}$, sepsis $^{17}$, lupus $^{18}$, diabetes ${ }^{19}$, psoriasis $^{20}$, nephropathy ${ }^{21}$, ischaemia-reperfusion injury ${ }^{22}$, obesity, and metabolic and cardiovascular dysfunction ${ }^{23}$. C3a also reportedly has antimicrobial $^{24}$ and antifungal ${ }^{25}$ activities. Despite these potent activities, C3a is rapidly degraded in vivo to C3a-desArg ${ }^{26}$, which has a different pharmacology from $\mathrm{C} 3 \mathrm{a}$ and does not bind to $\mathrm{C} \mathrm{aR}^{27}$, nor do commercially available antibodies discriminate between C3a and C3a-desArg ${ }^{22}$. Synthetic agonists that act through C3aR, but do not degrade as C3a does, can be expected to have immunostimulating and degranulating activities, whereas stable antagonists may be valuable new anti-inflammatory therapeutics. However, despite decades of effort by academia and the pharmaceutical industry, no small organic molecules have yet been reported as potent and selective C3aR agonists or antagonists ${ }^{28-32}$.

The crystal structure of $\mathrm{C} 3 \mathrm{a}^{33-35}$ reveals that its 77 amino acids adopt a well-defined helix bundle (Fig. 1a), with less structure in carboxy-terminal residues known to be critical for receptor activation $^{36}$. Mutagenesis of C3a and its receptor support a twosite binding model ${ }^{37}$. The helical bundle residues $1-69$ of C3a have high affinity for (but do not activate) the receptor, through multiple positive-charged lysine and arginine residues of C3a making complementary interactions with negative-charged Asp residues in the unusually large extracellular loop 2 (ECL2) at one site of the $\mathrm{C}_{3} \mathrm{aR}^{38,39}$. On the other hand, the C-terminal pentapeptide segment LGLAR of C3a has very low affinity for a second site on C3aR, leading to activation. Arg77 at the Cterminus of $\mathrm{C} 3 \mathrm{a}$ is critical for agonist activity; on removal, the resulting C3a-desArg does not bind to $\mathrm{C} \mathrm{aR}^{27}$. Moreover, mutagenesis of Arg161, Arg340 and Asp417 in the receptor has shown these residues to be crucial for $\mathrm{C} 3 \mathrm{a}$ binding and activation ${ }^{40}$. The essential Arg77 residue is the only charged residue near the $\mathrm{C}$ terminus of $\mathrm{C} 3 \mathrm{a}$ and is thought to interact with the above three charged residues of C3aR.

Here we exemplify the approach of growing a functionally important amino acid of a protein, namely the arginine from the $\mathrm{C}$-terminus of $\mathrm{C} 3 \mathrm{a}$, into small molecules that can execute the potent functions of the C3a protein, but are only a fraction of the size, cheaper to synthesize, and more chemically and biologically stable. We describe small molecules built from an amino acid template, incorporating a specific heterocycle to make a

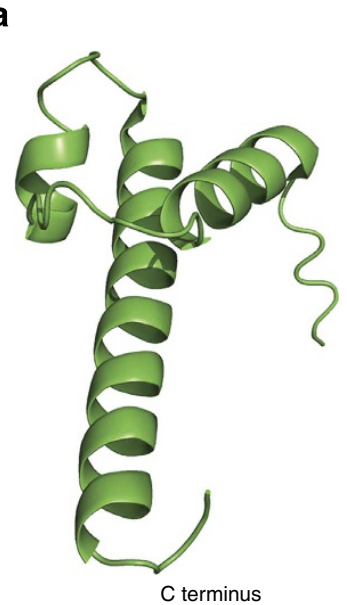

b

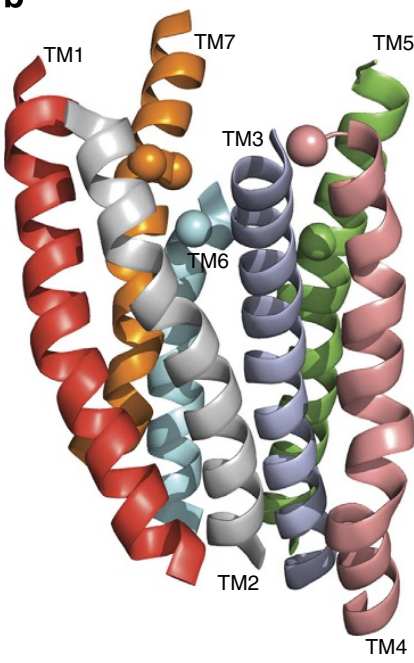

c

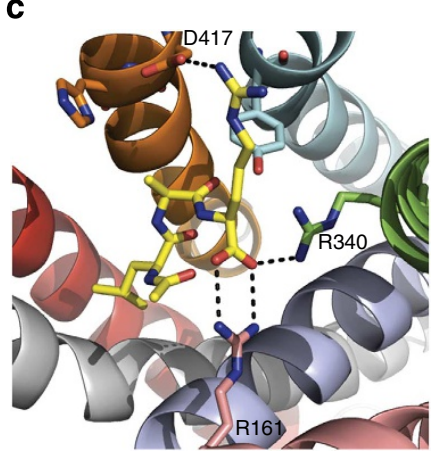

d

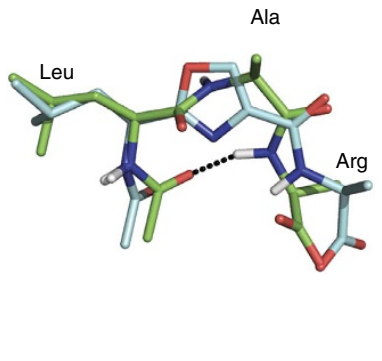

Figure 1 | Modelling C3aR interactions with Leu-Ala-Arg. (a) Structure of human C3a (pdb 4160). (b) Side view of seven transmembrane (7TM) region of $\mathrm{C} 3 \mathrm{aR}$ homology model derived from the crystal structure of human CXCR4 (bound to a cyclic peptide antagonist) ${ }^{41}$. C $\alpha$ of D417, R161, R340, H418 and Y393 rendered as solid spheres. (c) Ac-Leu-Ala-Arg (3, yellow) placed in the 7TM region of human C3aR, showing putative interactions with receptor residues D417 (TM7), R161 (TM4) and R340 (TM5) identified from mutagenesis ${ }^{38-40}$ to be important for binding to Arg77 of C3a. (d) A low-energy conformation of Ac-(Leu-Ox)-Arg (6, cyan carbons; Ox, oxazole) aligned well with Ac-Leu-Ala-Arg (3, green carbons) modelled in a type $\| \beta$ turn conformation $\left(\phi_{i+1}-60^{\circ}, \psi_{i+1} 120^{\circ}, \phi_{i+2} 80^{\circ}\right.$, $\left.\psi_{\mathrm{i}+2} \mathrm{O}^{\circ}\right)$, showing the typical $(\mathrm{i}, \mathrm{i}+3) \mathrm{H}$-bond Ac-CO...HN-Arg

(Arg side chains omitted for clarity).

important hydrogen bonds (H-bonds) with the C3a receptor and to control the shape of the molecule and orientation of its hydrophobic substituents. The small molecules have similar affinity for C3aR on human macrophages and comparable agonist potencies and functional profiles to $\mathrm{C} 3 \mathrm{a}$, as measured by intracellular calcium release and inflammatory gene expression in human macrophages and degranulation of human mast cells. Importantly, the small molecule agonists are stable in serum, unlike C3a that rapidly degrades with loss of the C-terminal arginine that is critical for binding of $\mathrm{C} 3 \mathrm{a}$ to its receptor C3aR. If generally applicable, this template approach could potentially be useful in creating small molecule surrogates of other proteins for applications in biology and medicine.

\section{Results}

C3aR homology model and ligand evolution. We therefore created a three-dimensional homology structural model for C3aR 
(Fig. 1b) and positioned only an arginine amino acid into $\mathrm{C} 3 \mathrm{aR}$ in the vicinity of those three receptor residues (Fig. 1c). A homology model of the human C3a receptor was generated, using the Prime module in the Schrödinger molecular modelling suite, based on aligning its sequence with that of the crystal structure of human chemokine receptor CXCR4 (bound to a cyclic peptide antagonist $^{41}$ (pdb code 3OE0). Models were created to focus on the seven transmembrane (7TM) helix domain, without the ECL2, which in C3aR consists of 170 amino acids and is inherently flexible and difficult to model (Fig. 1b). An arginine molecule was specifically placed in this model, near receptor residues Arg161, Arg340 and Asp417, to simulate Arg77 of the C3a ligand. The negatively charged carboxylate terminus of Arg77 in C3a interacts with cationic side chains of both Arg161 and Arg340, whereas the protonated guanidinium side chain of Arg77 interacts with the carboxylate side chain of Asp417 (Fig. 1c). These three contact points are consistent with C3aR/ C3a mutagenesis data, indicating complementarity between Arg77 in $\mathrm{C} 3 \mathrm{a}$ and the above three residues of $\mathrm{C}_{3} \mathrm{aR}^{38-40}$. On the basis of this location for Arg77, we identified space that could be occupied by attached amino acids Ala76 and Leu75 of C3a, thereby indicating where a small tripeptide ligand LAR might bind in C3aR. This was the basis for our strategy to rationally design and grow novel small molecule ligands from an arginine point template corresponding to Arg77 of C3a, notwithstanding the large uncertainties of ligand docking in a three-dimensional model of a GPCR.

Structure-activity relationships. Tripeptides Leu-Ala-Arg (2), Ac-Leu-Ala-Arg (3) and Boc-Leu-Ala-Arg (4) did not show any detectable binding to $\mathrm{C} 3 \mathrm{aR}$ or agonist activity at or below $1 \mathrm{mM}$, the highest concentration tested, on human monocytederived macrophages (HMDMs) (Table 1). Next, we sought to establish whether there were residues present in the 7TM-binding cavity and/or the ECLs that could potentially form additional $\mathrm{H}$-bonding interactions with the backbone of Leu or Ala from the tripeptide Leu-Ala-Arg. Three receptor residues were conspicuous as prospective $\mathrm{H}$-bond donors in the proximity of the Ala attached to Arg, namely Tyr393 from TM6 and His418 from TM7 (Fig. 1c), and possibly Tyr174 from ECL2, although the latter position is very uncertain owing to ECL2 flexibility.

Table 1 | Binding affinity and agonist potency of ligands for C3aR on human macrophages.

\begin{tabular}{|c|c|c|c|c|c|c|}
\hline & Compound & Binding $I C_{50}(n M)^{\star}$ & Binding plC $\mathrm{po}_{50} \pm$ s.e.m. & n & Agonist $\mathrm{EC}_{50}(\mu \mathrm{M})^{\dagger}$ & Agonist pEC $\mathrm{Co}_{50} \pm$ s.e.m. \\
\hline 1 & $\mathrm{C} 3 \mathrm{a}$ & 0.07 & $10.1 \pm 0.2$ & $>3$ & 0.04 & $7.4 \pm 0.07$ \\
\hline 2 & Leu-Ala-Arg & $>1,000,000$ & $<4.0$ & 3 & $>1,000$ & $<4.0$ \\
\hline 3 & Ac-Leu-Ala-Arg & $>1,000,000$ & $<4.0$ & 3 & $>1,000$ & $<4.0$ \\
\hline 4 & Boc-Leu-Ala-Arg & $>1,000,000$ & $<4.0$ & 3 & $>1,000$ & $<4.0$ \\
\hline 5 & H-(Leu-Oxazole)-Arg & 560 & $6.2 \pm 0.4$ & 3 & $>100$ & $<4.0$ \\
\hline 6 & Ac-(Leu-Oxazole)-Arg & 30 & $7.5 \pm 0.2$ & 3 & 0.17 & $6.8 \pm 0.1$ \\
\hline 7 & Boc-(Leu-Oxazole)-Arg & 12 & $7.9 \pm 0.2$ & 8 & 0.06 & $7.2 \pm 0.1$ \\
\hline 8 & Boc-(Ile-Oxazole)-Arg & 34 & $7.5 \pm 0.2$ & 3 & 0.02 & $7.7 \pm 0.2$ \\
\hline 9 & Boc-(Cha-Oxazole)-Arg & 99 & $7.0 \pm 0.2$ & 3 & 0.21 & $6.7 \pm 0.3$ \\
\hline 10 & Boc-(Ala-Oxazole)-Arg & $>100,000$ & $<4.0$ & 3 & $>100$ & $<4.0$ \\
\hline 11 & Boc-(Leu-Thiazole)-Arg & 375 & $6.4 \pm 0.3$ & 3 & $\ddagger$ & $\ddagger$ \\
\hline 12 & Boc-(Leu-Imidazole)-Arg & 51 & $7.3 \pm 0.3$ & 3 & 0.12 & $6.9 \pm 0.1$ \\
\hline 13 & Boc-(Leu-N-Me(Y)-Imidazole)-Arg & 47 & $7.3 \pm 0.3$ & 3 & 0.06 & $7.2 \pm 0.1$ \\
\hline 14 & Boc-(Leu-N-Me(X)-Imidazole)-Arg & $>10,000$ & $<5.0$ & 3 & 9.4 & $5.0 \pm 0.1$ \\
\hline 15 & Boc-(Leu-1,3,4-Oxadiazole)-Arg & 997 & $6.0 \pm 0.5$ & 3 & $>100$ & $<4.0$ \\
\hline 16 & 3-Indole-(Leu-Imidazole)-Arg & 12 & $7.9 \pm 0.3$ & 3 & 0.015 & $7.8 \pm 0.3$ \\
\hline 17 & 3-Indole-(Leu-Oxazole)-Arg & 4 & $8.4 \pm 0.3$ & 5 & 0.007 & $8.1 \pm 0.2$ \\
\hline
\end{tabular}

$\mathrm{EC}_{50}$, half maximal effective concentration; $\mathrm{HMDM}$, human monocyte-derived macrophage; $\mathrm{I}_{50}$, half maximal inhibitory concentration.

${ }^{*}$ Concentration of ligand required to inhibit $50 \%$ of $\left[{ }^{125} \mathrm{I}\right]-\mathrm{C} 3 \mathrm{a}(80 \mathrm{pM})$ binding to HMDMs.

+Concentration of ligand causing $50 \%$ of $\mathrm{Ca}^{2+}$ release in $\mathrm{HMDMs}$ relative to $100 \%$ induced by $\mathrm{C} 3 \mathrm{a}$ at $1 \mu \mathrm{M}$.

$\ddagger$ This compound showed partial agonist activity at concentrations $\geq 1 \mu \mathrm{M}$

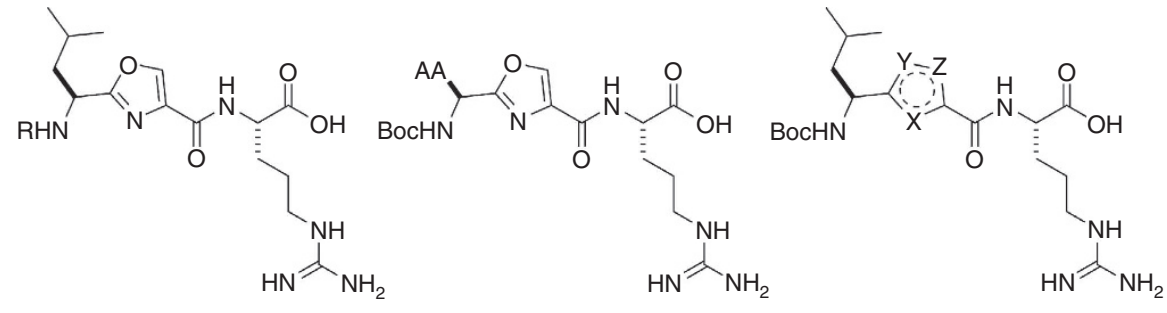

$$
\begin{array}{ll}
5 \mathrm{R}=\mathrm{H} & 7 \mathrm{AA}=\mathrm{Leu} \\
6 \mathrm{R}=\mathrm{Ac} & 8 \mathrm{AA}=\mathrm{Ile} \\
& 9 \mathrm{AA}=\mathrm{Cha} \\
& 10 \mathrm{AA}=\text { Ala }
\end{array}
$$

$$
\begin{aligned}
& 11 X=S, Y=N, Z=C-M e \\
& 12 X=N, Y=N, Z=C-M e \\
& 13 X=N, Y=N-M e, Z=C-M e \\
& 14 X=N-M e, Y=N, Z=C-M e \\
& 15 X=O, Y=N, Z=N
\end{aligned}
$$<smiles>Cc1[nH]c([C@H](CC(C)C)NC(=O)c2c[nH]c3ccccc23)nc1C(=O)N[C@@H](CCCNC(=N)N)C(=O)O</smiles><smiles>CC(C)C[C@H](NC(=O)c1c[nH]c2ccccc12)c1nc(C(=O)N[C@@H](CCCNC(=N)N)C(=O)O)co1</smiles>

Figure 2 | Synthesised C3aR ligands. Chemical structures of compounds 5-17, synthesized as detailed in the Methods (16,17) and Supplementary Methods (5-15). 
Although GPCR models are notoriously flexible and thus of uncertain accuracy, we decided to test whether H-bond acceptors strategically placed at the Ala position might increase affinity for $\mathrm{C} 3 \mathrm{aR}$, thereby confirming the idea that an $\mathrm{H}$-bond donor might be nearby its binding site in C3aR. Ala in Leu-Ala-Arg was therefore replaced with oxazole $(\mathrm{Ox})$, which positions a known $\mathrm{H}$-bond-accepting nitrogen atom of Ox within (Leu-Ox)-Arg for potential interaction with a putative H-bond donor Tyr393, His418 or Tyr174. This ligand change from Leu-Ala-Arg (2) to (Leu-Ox)-Arg (5) resulted in a $>1,000$-fold increase in affinity for $\mathrm{C} 3 \mathrm{aR}$ and some measurable, albeit weak, agonist activity (Table 1). Importantly, structure-activity optimization does not rely on knowing the identity of the interacting $\mathrm{H}$-bond donor in C $3 a R$. Figure 2 details the chemical structure of ligand 5 and further modified ligands $\mathbf{6}-\mathbf{1 7}$ to be discussed below.

The magnitude of the increase in affinity cannot be accounted for solely by one $\mathrm{H}$-bond to the $\mathrm{Ox}$, and is in part also attributed to the known turn-inducing constraint imposed by this heterocycle, conferring some structure in water to an otherwise unstructured tripeptide unit. Most peptide-activated GPCRs bind to a $\beta / \gamma$-turn conformation of endogenous agonists ${ }^{42}$, and incorporation of a turn mimetic often pre-organizes agonists in a receptor-bound turn conformation. An alignment using ROCS (rapid overlay of chemical structures, version 3.1.2, OpenEye Scientific Software) of low-energy conformers generated with Omega (version 2.4.3, OpenEye Scientific Software) of Ac-LeuAla-Arg (3) with Ac-(Leu-Ox)-Arg (6) indicated that a $\beta$-turn conformation of the former was mimicked by the latter (Fig. 1d). The plane of the Ox ring is perpendicular to the plane of the Leu amide carbonyl, favourably aligning for making a $\mathrm{H}$-bond interaction (Fig. 1d). In support of formation of this additional H-bond, attaching a carbonyl group to the amino terminus of $\mathbf{5}$ (for example, Ac in Ac-(Leu-Ox)-Arg, 6; Boc in Boc-(Leu-Ox)Arg, 7) caused $\sim 20$ - and $\sim 50$-fold increases in ligand affinity for C3aR and $\sim 10^{3}$-fold greater agonist activity than for 5 (Table 1). In combination, these data support both the heterocycle nitrogen and the $\mathrm{N}$-terminal carbonyl oxygen being important $\mathrm{H}$-bond acceptors that contribute to the spectacular increase in receptor binding and agonist function.

Modifying side chains and heterocycles. Further modifications of the leucine side chain to isoleucine (8) caused a 3-fold loss of affinity, to the larger side chain of cyclohexylalanine $(9)$ reduced binding affinity 8 -fold and agonist potency 3 -fold, whereas reducing the size of the side chain to alanine (10) reduced affinity and agonist activity by over 1,000-fold. Thus, the leucine side chain is important and essential for binding to C3aR and contributes a factor of at least $10^{3}$ to agonist binding and function.

On the basis of the promising results for Ox in compound 7, other five-membered aromatic heterocycles were incorporated to identify the contribution of the heterocycle $\mathrm{H}$-bond acceptor to agonist potency. The theoretical $\mathrm{H}$-bond interaction energy between a water molecule and each heterocycle was determined using models minimized by $a b$ initio methods at the MP2/6 $311++\mathrm{g}(3 \mathrm{~d}, 3 \mathrm{p})$ level of theory using Gaussian 09 (ref. 43). Strong interactions were predicted for the trigonal nitrogen atoms of imidazole and Ox rings, whereas much weaker $\mathrm{H}$-bonds are likely for the oxygen of oxadiazole and sulphur or $\pi$ system of thiazole. $\mathrm{N}$-methylation in the inactive compound 14 precluded $\mathrm{H}$-bond formation, so the H-bond interaction energy was set at zero (Fig. 3a). For this small series of heterocycles incorporated into Boc-Leu-Ala-Arg to produce compounds 7 and 11-15, there was a linear correlation between $\mathrm{H}$-bond interaction energy (over a $35 \mathrm{~kJ} \mathrm{~mol}^{-1}$ range), calculated for the respective $\mathrm{H}$-bond acceptor interacting with water, and the binding affinity (over 4
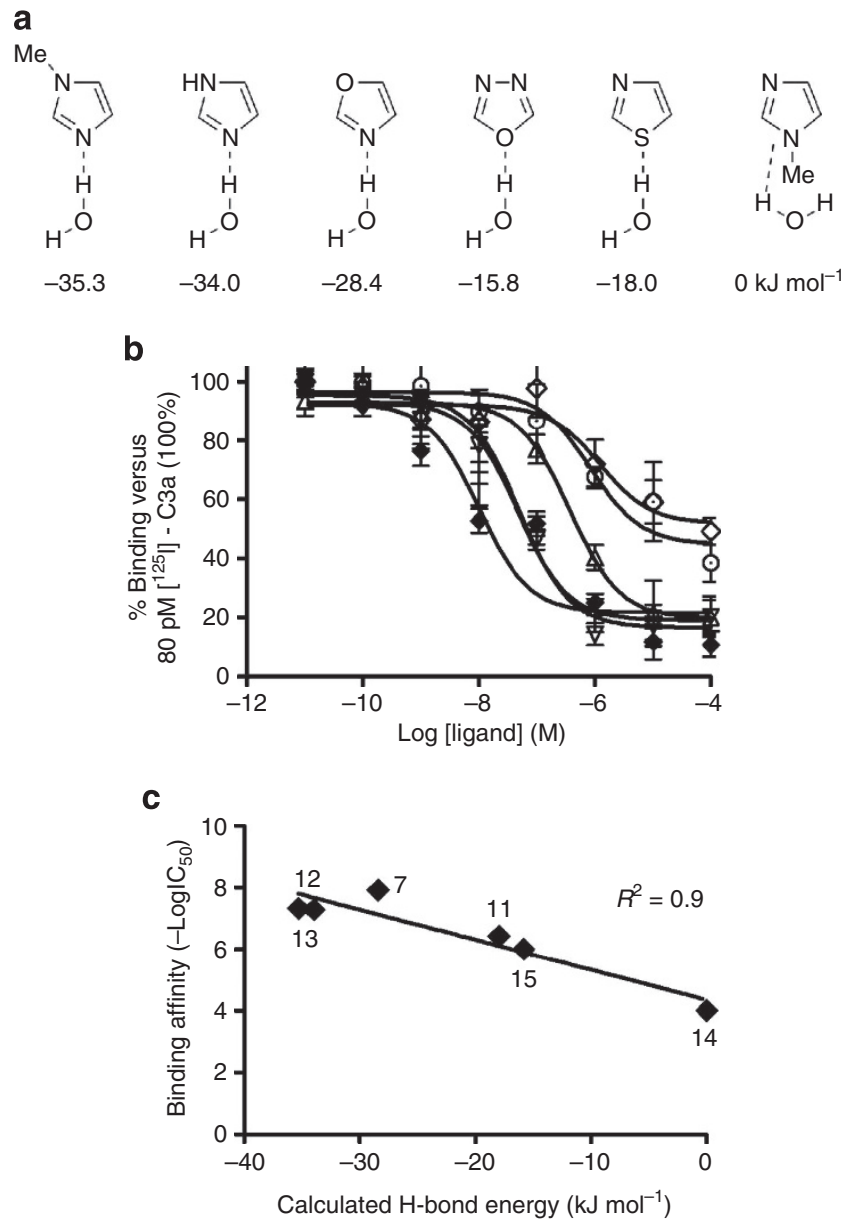

Figure 3 | Effect of heterocycles on ligand binding to C3aR. (a) Calculated (MP2/6-311 + + g(3d,3p)) (ref. 43) H-bond interaction energy $\left(\mathrm{kJ} \mathrm{mol}^{-1}\right.$ ) predicted between water and a heteroatom of heterocycles. (b) C3aRbinding affinty of compounds $\mathbf{7}$ (black diamonds, oxazole), 11 (triangles, thiazole), 12 (inverted triangles, imidazole), 13 (cross, $\mathrm{NMe}(\mathrm{Y})$-imidazole), 14 (circle, $\mathrm{NMe}(\mathrm{X})$-imidazole), 15 (white diamonds, oxadiazole) measured by competition with $\left.{ }^{125} \mathrm{I}\right]-\mathrm{C} 3 \mathrm{a}(80 \mathrm{pM})$ in HMDMs. Error bars are means \pm s.e.m. (c) Linear correlation between C3aR-binding affinity $\left(-\log \mid C_{50}\right)$ and calculated $\mathrm{H}$-bond interaction energy $\left(\mathrm{kJ} \mathrm{mol}^{-1}\right)$ predicted for water binding to different heterocyclic compounds 7 and 11-15.

log units) of the ligand for C3aR (Fig. 3b,c). Positioning of the $\mathrm{H}$-bond-accepting atom was an important determinant of agonist potency, the $\mathrm{X}$ position being more important than $\mathrm{Y}$ or $\mathrm{Z}$ positions (Table 1), highlighted by the $N$-methyl imidazole substituents in 13 versus 14 .

Having identified imidazole and $\mathrm{Ox}$ as optimal heterocycle modifications, the $\mathrm{N}$-terminal Boc group was next replaced to seek greater agonist potency. The indole-3-carboxamide derivatives 16 and $\mathbf{1 7}$ showed approximately threefold greater binding affinity and almost tenfold greater agonist activity than $\mathbf{1 2}$ and 7, respectively. These observed enhancements may be due to the indole ring making an additional $\pi$-stacking interaction with His418 and occupying a larger region of hydrophobic space in the $\mathrm{C} 3 \mathrm{a}$ receptor. Concentration-response curves are compared (Fig. 4a) for C3a versus the most potent small molecule agonist above, compound $\mathbf{1 7}$ (also named TR16), in the intracellular $\mathrm{Ca}^{2+}$ release assay using HMDMs. It is apparent that $\mathbf{1 7}$ shows a full agonist response comparable to $\mathrm{C} 3 \mathrm{a}$, but that $\mathbf{1 7}$ is almost an order of magnitude more active $\left(\mathrm{EC}_{50}\right.$ (half maximal effective 
a

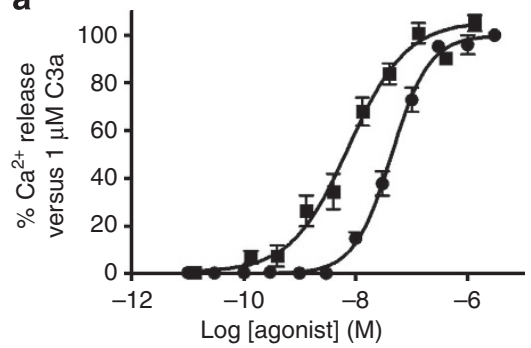

C
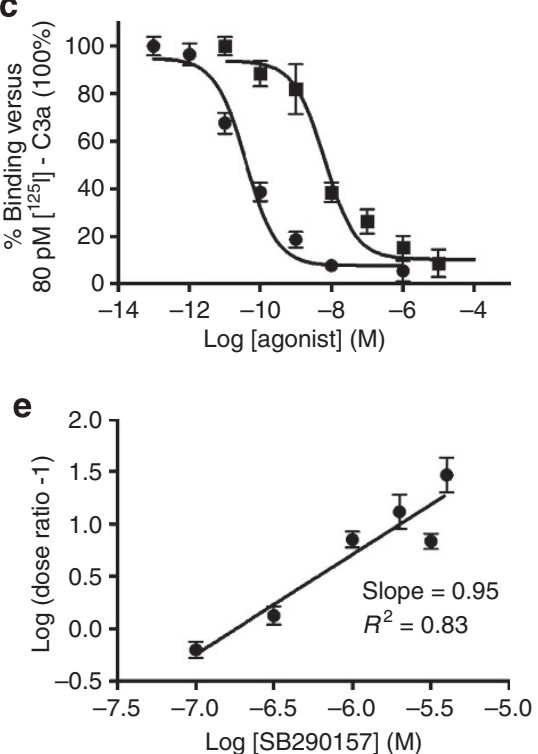

b

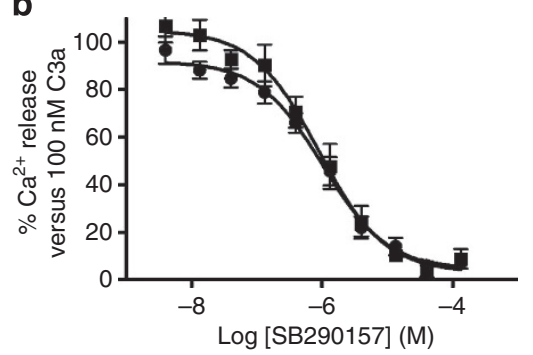

d

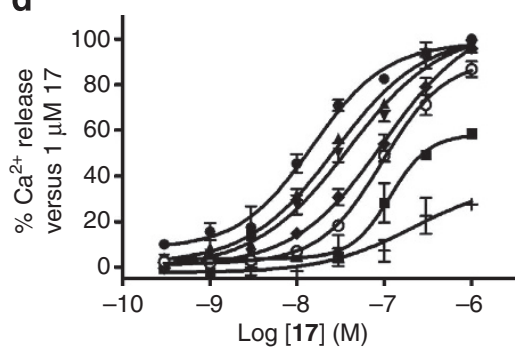

f

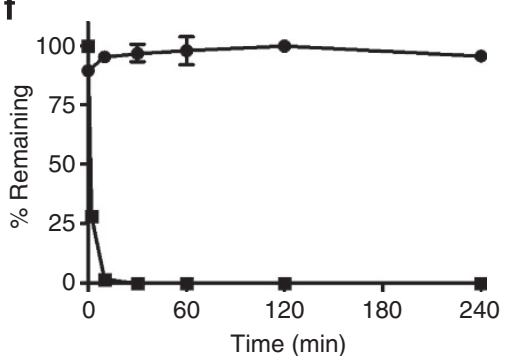

Figure 4 | Affinity and $\mathbf{C a}^{2}+$ mobilization for C3a versus 17. (a) $\mathrm{iCa}^{2+}$ mobilization induced in HMDMs by compound $\mathbf{1 7}$ (squares) versus $\mathrm{C} 3 \mathrm{a}$ (circles) at various concentrations, relative to $100 \%$ fluorescence for $1 \mu \mathrm{M} \mathrm{C3a}(n \geq 3)$. Agonist $\mathbf{1 7}$ is $>5$-fold more potent than C3a. (b) SB290157 inhibits intracellular $\mathrm{Ca}^{2}+$ release induced in HMDMs by either C3a (circles, $100 \mathrm{nM}$ ) or compound $\mathbf{1 7}$ (squares, $100 \mathrm{nM}$ ), with comparable inhibitory potency $\left(\mathrm{IC}_{50} 1.0 \mu \mathrm{M}, n \geq 3\right.$ ). (c) C3aR-binding affinities of compound 17 (squares) versus C3a (circles) measured by displacement of ${ }^{125} \mathrm{I}-\mathrm{C} 3 \mathrm{a}$ ( $80 \mathrm{pM}$ ) ( $n>3$ ), the higher affinity of the latter owing to the additional helical domain of C3a. (d) Concentration-response for agonist $\mathbf{1 7} \pm$ antagonist SB290157 at various concentrations (zero, closed circles; $0.1 \mu \mathrm{M}$, triangles; $0.3 \mu \mathrm{M}$, inverted triangles; $1.0 \mu \mathrm{M}$, diamonds; $2.0 \mu \mathrm{M}$, squares; $3 \mu \mathrm{M}$, open circles; $4 \mu \mathrm{M}$ cross; $n=3$ ). (e) Schild plot (slope $=0.95$ ) of data from Fig. 4d, indicating competitive inhibition of 17 by SB290157. (f) Unlike C3a (not shown), 17 (circles) was intact in rat plasma after $4 \mathrm{~h}$ (at $37^{\circ} \mathrm{C}, \mathrm{pH} 7.4$, initial concentration $1 \mu \mathrm{M}$ ), whereas linear peptide $\mathbf{4}$ (squares) was rapidly degraded and undetectable after $10 \mathrm{~min}$, as measured by liquid chromatography mass spectroscopy (LCMS) $(n=3)$. Error bars are means \pm s.e.m.

concentration) $7 \mathrm{nM}$ versus $40 \mathrm{nM}$ ). Moreover, this agonist activity for both $\mathrm{C} 3 \mathrm{a}$ and $\mathbf{1 7}$ was dose-dependently inhibited to the same degree by a known, albeit weakly potent antagonist of C3aR (SB290157, IC $_{50}$ (half maximal inhibitory concentration) $1 \mu \mathrm{M}$ versus $\mathrm{C} 3 \mathrm{a}$ at $1 \mu \mathrm{M})^{28,29}$, consistent with the effect being mediated in both cases by C3aR (Fig. 4b). The high agonist potencies of $\mathbf{1 7}$ and $\mathrm{C} 3 \mathrm{a}$ are, in spite of their quite different affinities for $\mathrm{C} 3 \mathrm{aR}$ (Fig. 4c), the much greater affinity of $\mathrm{C} 3 \mathrm{a}$ being due to its additional large helical domain that binds to an extracellular region of the receptor. The presence of this highaffinity receptor-anchoring domain in $\mathrm{C} 3 \mathrm{a}$ provides a high effective molarity for the receptor-activating C-terminus of C3a, which is otherwise a weakly binding and very feeble agonist (compound 1, Table 1). Altering concentrations of both 17 and SB290157 (ref. 29) revealed competition between the compounds, evidenced by a horizontal shift to the right in agonist plots (Fig. 4d), with a Schild plot slope $\sim 1$ (Fig. 4e) consistent with both compounds binding to the same or overlapping site on C3aR. An important advantage of compound $\mathbf{1 7}$ over C3a is that 17 remains intact after exposure to plasma, whereas the arginine is cleaved from C3a within minutes in plasma (Fig. 4f) by carboxypeptidases $^{26}$. The product of this cleavage is C3a-desArg, which has quite a different pharmacology and a different receptor ${ }^{44}$; thus, C3a is actually of little value as a tool to probe $\mathrm{C} 3 \mathrm{aR}-\mathrm{mediated}$ functions induced in vivo by constitutive C3a. The plasma stability of small molecule agonists such as $\mathbf{1 7}$ is likely to be of enormous benefit for in vivo studies, provided that they display other comparable functional responses to $\mathrm{C} 3 \mathrm{a}$, and can therefore be used as small molecule surrogates for C3a (see ahead).

Profiling additional agonist functions. Compound $\mathbf{1 7}$ was thus also compared with recombinant human $\mathrm{C} 3 \mathrm{a}$ for other functional agonist responses using different assays and different cells. Figure $5 \mathrm{a}-\mathrm{c}$ shows that $\mathrm{C} 3 \mathrm{a}$ and $\mathbf{1 7}$ induce comparable profiles of expression of the inflammatory genes $I L 8, C C L 3, F O S B, I L 6$ and EGR1 in HMDMs. Moreover, IL1 $\beta$ and TNF gene expression induced by either $\mathrm{C} 3 \mathrm{a}$ or $\mathbf{1 7}$ was blocked by the known ${ }^{29}$, but very weakly potent C3aR antagonist SB290157, by pertussis toxin that decouples $\mathrm{C} 3 \mathrm{aR}$ from $\mathrm{Gi}$, and by the PLC $\beta$ inhibitor U73122 that blocks $\mathrm{C} 3 \mathrm{aR}-$ mediated $\mathrm{Ca}^{2}+$ release (Fig. 5b,c). These effects are consistent with the actions of $\mathbf{1 7}$ being mediated through $\mathrm{C} 3 \mathrm{aR}$ and point to comparable potencies with $\mathrm{C} 3 \mathrm{a}$ in the responses being measured. Finally, in different human immune cells, both $\mathrm{C} 3 \mathrm{a}$ and 17 at $\mathrm{nM}$ to $\mu \mathrm{M}$ concentrations induced 
a

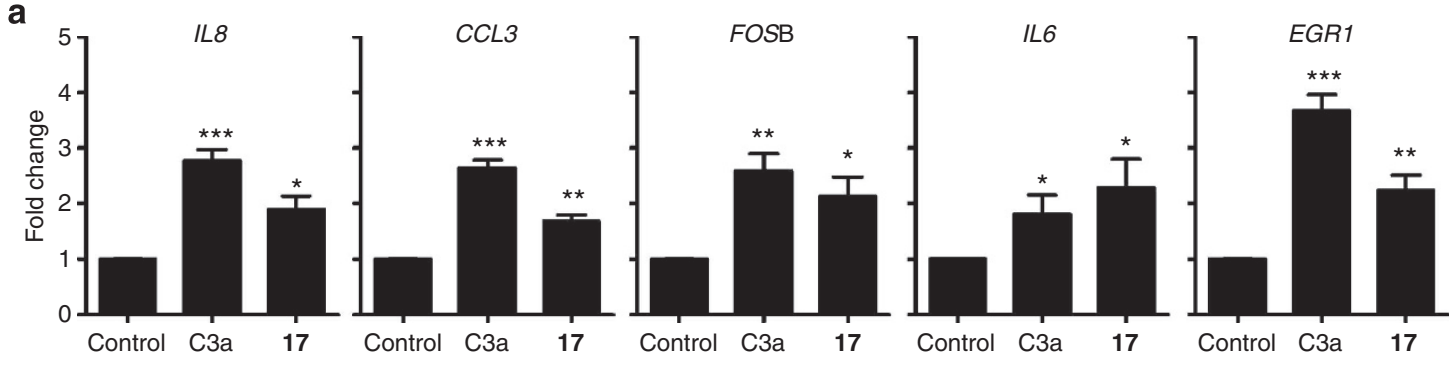

b

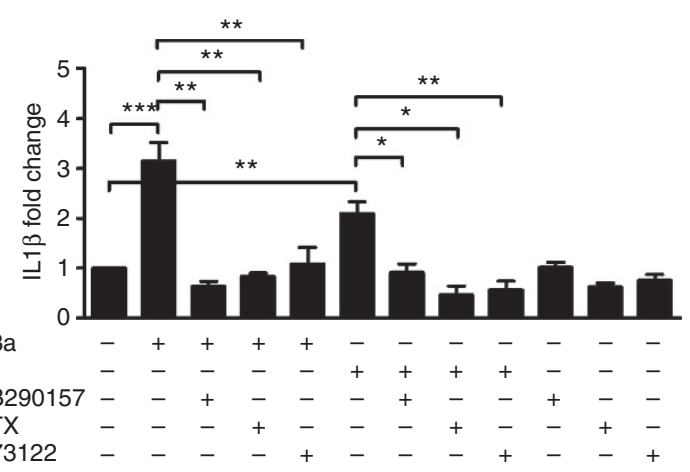

d

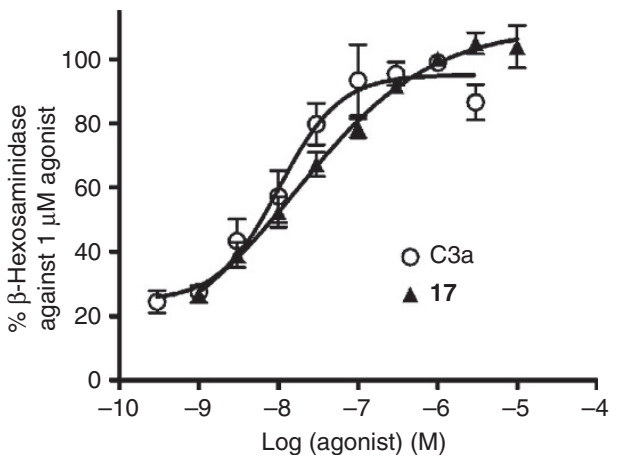

C

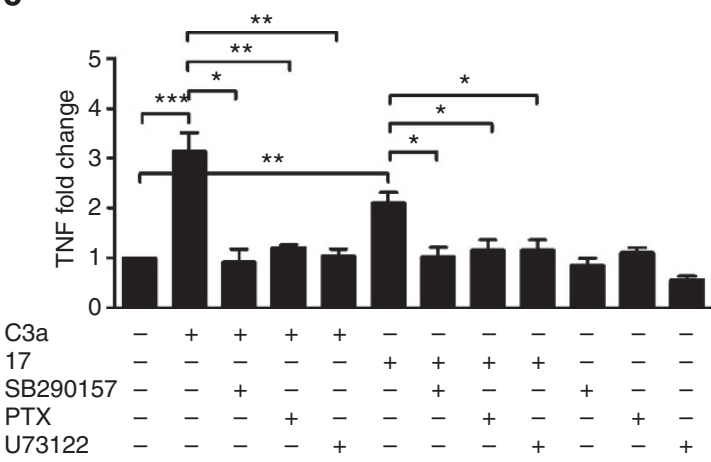

e

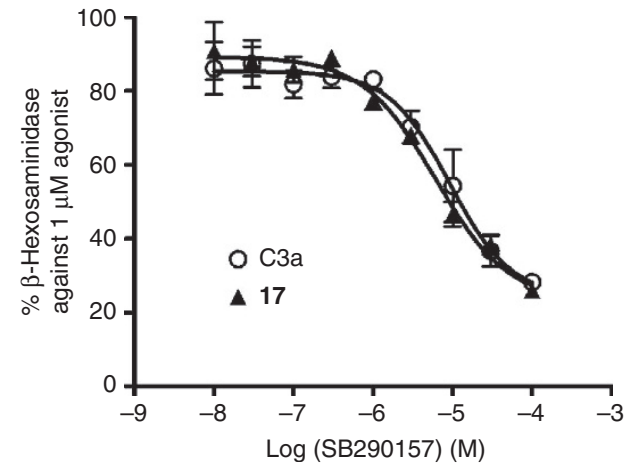

Figure 5 | Inflammatory gene expression and degranulation induced by C3a versus 17. (a) C3a or $\mathbf{1 7}(0.3 \mu \mathrm{M}, 30$ min) induce expression of inflammatory genes in HMDMs, monitored by quantitative reverse-transcriptase PCR. Relative gene expression data are duplicates normalized to housekeeping gene 18S. Fold changes were calculated against untreated control. Error bars represent mean \pm s.e.m. of at least three independent experiments. ${ }^{\star} P<0.05 ;{ }^{\star \star} P<0.01$; ${ }^{\star \star} P<<0.005$. (b,c) Expression in HMDMs of inflammatory genes IL1 $\beta$ and TNF induced by C3a or $\mathbf{1 7}(0.3 \mu \mathrm{M}, 30 \mathrm{~min})$ alone or after preincubating cells with C3aR antagonist (10 $\mu \mathrm{M} \mathrm{SB290157,30} \mathrm{min),} \mathrm{G \alpha i} \mathrm{inhibitor} \mathrm{(} 200 \mathrm{ng} \mathrm{ml} \mathrm{m}^{-1}$ pertussis toxin (PTX), overnight) or PLC $\beta$ inhibitor $(10 \mu \mathrm{M}$ U73122, $30 \mathrm{~min})$. (d,e) $\beta$-Hexosaminidase release mediated by $\mathrm{C} 3 a\left(\mathrm{pEC} 508.0 \pm 0.3\right.$ ) and $\mathbf{1 7}$ ( $\left.\mathrm{pEC} \mathrm{C}_{50} 7.8 \pm 0.6\right)$ in the absence or presence of SB290157 in LAD2 human mast cells. Cells were pre-sensitized with lgE (100 ng ml ${ }^{-1}$, overnight) before adding C3a (1 $\mu \mathrm{M}$ at 1.5 log dilutions) or 17 (10 $\mu \mathrm{M}$ at 1.5 dilutions) for $30 \mathrm{~min}$. In the antagonist assay, cells sensitized overnight with IgE were incubated with SB290157 (100 $\mu$ M at 1.5 log dilutions, $30 \mathrm{~min}$ ) before adding C3a or $\mathbf{1 7}(1 \mu \mathrm{M})$ for $30 \mathrm{~min}$. Release of $\beta$-hexosaminidase in cell supernatant and lysate was detected by adding $\mathrm{p}$-nitrophenyl $N$-acetyl- $\beta$-D-glucosamide (PNAG) and reading absorbance at $405 \mathrm{~nm}$. \% $\beta$-Hexosaminidase release was calculated against response for $1 \mu \mathrm{M}$ agonist. Error bars represent mean \pm s.e.m. of $(n=4)$ independent experiments.

degranulation of human mast cells to the same extent, as measured by comparable release of hexosaminidase (Fig. 5d). Further, this agonist response was inhibited to the same extent for C3a and 17 by SB290157 (Fig. 5e). These data give very strong support for compound $\mathbf{1 7}$ being a viable, equipotent, functional surrogate for the human $\mathrm{C} 3 \mathrm{a}$ protein. We expect that this compound class can be further developed into valuable drug-like agonists and antagonists for treating C3aR-mediated diseases.

\section{Discussion}

A method has been described for downsizing a protein to an equipotent functional small molecule, a method that does not require a crystal structure for the protein but does rely on some knowledge of the activating region of the protein. The C3a protein chosen here for mimicry has its functional activity localized at its C-terminus, but requires the remainder of the protein for high affinity binding to the receptor to elicit agonist activity and high potency. In this study, the high affinity binding domain of $\mathrm{C} 3 \mathrm{a}$ has been removed, but compensated for by making rational changes to small molecule mimics of the C-terminal tripeptide segment of C3a, namely Leu-Ala-Arg. These changes impart $\mathrm{H}$-bond-accepting properties, introduce a turn-inducing heterocycle and enhance space-filling properties of the small molecule analogues. The results convincingly demonstrate that a number of compounds $(7,8,13,16$ and 17) have equipotent agonist activity to the protein $\mathrm{C} 3 \mathrm{a}$, as measured by 
induction of intracellular $\mathrm{Ca}^{2+}$ release in human macrophages (Table 1). The most potent compound (17) was examined in more detail in other cellular assays, with mimicry of potent C3a function also extending to C3aR-mediated expression of all seven selected inflammatory genes in human macrophages and to C3aR-mediated degranulation of human mast cells. These immunostimulating properties for $\mathbf{1 7}$ are the same as for human $\mathrm{C} 3 \mathrm{a}$, validating successful functional mimicry of a protein by a small molecule across a range of inflammatory and cellular readouts.

Through structure-activity relationships, it has been shown that six factors contribute to the spectacular agonist potencies of these compounds, which are approximately six orders of magnitude more potent than the Leu-Ala-Arg tripeptide component of C3a but are not much different in size. (1) These compounds possess an important arginine, just like the critical C-terminal arginine of human $\mathrm{C} 3 \mathrm{a}$, which imparts some binding affinity for C3aR. (2) All compounds possess an Ox or imidazole heterocycle, which also provides (3) a strong H-bond-accepting nitrogen atom, as well as (4) subtly altering the position of the Leu/Ile side chain in the dipeptide surrogate (Leu/Ile-heterocycle) versus Leu/Ile-Ala. These compounds further share (5) the presence of an $\mathrm{N}$-terminal carbonyl group that can make an additional H-bond interaction with C3aR and (6) a Boc/Indole capping group that can fill additional space in the receptor. The relative contributions made by each of these components to ligand affinity and agonist potency were ascertained via structure-activity relationship studies (Table 1).

Collectively, these features have led to the rational development of small molecules (molecular weight $<500 \mathrm{Da}$ ) with high affinity and specificity for the human $\mathrm{C} 3 \mathrm{a}$ receptor and comparable agonist potencies to C3a. The most potent compound was profiled more extensively in multiple additional assays where it was found to have the same C3aR-mediated functional profile, selectivity, activities and potencies as human $\mathrm{C} 3 \mathrm{a}$ protein. Compound $\mathbf{1 7}$ was shown to be a potent and C3aRselective agonist surrogate for C3a (Supplementary Fig. S5), with the advantage of being plasma stable unlike $\mathrm{C} 3 \mathrm{a}$, which rapidly loses its C-terminal arginine along with its affinity for and function through the receptor for C3a. Moreover, all the small molecules described herein can be made at a fraction of the thousands of dollars per milligram cost commercially charged for human C3a.

This approach to potent small molecule protein mimics may be transferable to the development of highly potent small molecule mimics of other proteins, including other GPCRactivating proteins. It is based on a very general premise, that one may only need to know that an amino acid of a protein (arginine here) is important for binding at a particular site on a receptor protein, in this case through known effects on the donor protein of site-directed mutagenesis of the receptor protein. This single amino acid can then be grown through a novel method of appending a H-bond-making entity, heterocycles with graded $\mathrm{H}$-bond acceptor versus $\mathrm{H}$-bond donor properties being chosen here to illustrate the idea. In principle, this $\mathrm{H}$-bond making appendage could be placed anywhere, on one side or the other side, or both sides of the arginine (or other point template) or further away. On finding measurable affinity, the putative $\mathrm{H}$-bond interaction can be rationally optimized by increasing the $\mathrm{H}$-bonding power, then by modifying the next position adjacent to the heterocycle-arginine motif to rationally improve binding and optimize function. Although only exemplified here for one protein, this is a potentially general approach. It remains to be determined whether its utility is also general for developing small molecules with the functional potencies of other proteins.

\section{Methods}

General methods. All reagents were purchased from Sigma-Aldrich or ChemImpex International Inc. Solid- and solution-phase chemistry approaches were used to synthesize all final compounds. The purity of each compound investigated was confirmed by ${ }^{1} \mathrm{H}$ NMR spectroscopy, HPLC and high-resolution mass spectra (HRMS). All compounds assayed were $\geq 95 \%$ pure. The syntheses and characterization of compounds $\mathbf{2 - 1 5}$ are reported in Supplementary Methods and reaction schemes and spectroscopic data are provided in Supplementary Figs S2-S20. The production and characterization of the two most potent compounds, 16 and 17, are described below. All final compounds were purified by reversedphase HPLC. Preparative-scale reversed-phase HPLC (rpHPLC) separations were performed on a Phenomenex Luna C18 $10 \mu \mathrm{m}, 250 \times 30.0 \mathrm{~mm}$ column. Standard conditions were used for elution of all compounds, unless otherwise indicated, at a flow rate of $40 \mathrm{ml} \mathrm{min}^{-1}: 100 \%$ A to $100 \%$ B linear gradient over $15 \mathrm{~min}$, followed by a further $10 \mathrm{~min}$ at $100 \% \mathrm{~B}$ where solvent $\mathrm{B}$ was $90 \% \mathrm{MeCN}, 10 \% \mathrm{H}_{2} \mathrm{O} \pm 0.1 \%$ TFA and solvent $\mathrm{A}$ was $\mathrm{H}_{2} \mathrm{O} \pm 0.1 \%$ TFA. Compounds were detected by ultraviolet absorption and pure fractions were lyophilized. Analytical rpHPLC was used to assess compound purity (Phenomenex Luna C18 column, $5 \mu \mathrm{m}, 90 \AA$,

$4.6 \times 250 \mathrm{~mm}$, at three different wavelengths $\lambda=214,230$ and $254 \mathrm{~nm}$ ). Standard conditions (same as preparative-scale rpHPLC) were used for all compounds, unless otherwise indicated, at a flow rate of $1 \mathrm{ml} \mathrm{min}^{-1}$. Solvents were the same as for preparative-scale rpHPLC. All final compounds were $\geq 95 \%$ pure by analytical HPLC. Electrospray ionization mass spectra measurements were obtained on Micromass LCT. HRMS measurements were obtained on a Bruker microTOF mass spectrometer equipped with a Dionex LC system (Chromeleon) in positive ion mode by direct infusion in $\mathrm{MeCN}$ at $100 \mu \mathrm{h} \mathrm{h}^{-1}$ using sodium formate clusters as an internal calibrant. Data were processed using Bruker Daltonics DataAnalysis 3.4 software. Mass accuracy was consistently better than 1 p.p.m. error. ${ }^{1} \mathrm{H}$ and ${ }^{13} \mathrm{C}$ NMR spectra were recorded on Bruker Avance 600 or Varian 400 spectrometers at $298 \mathrm{~K}$ in the deuterated solvents indicated and were referenced to the residual ${ }^{1} \mathrm{H}$ signals; DMSO- $\mathrm{d}_{6} 2.50$ p.p.m. and $\mathrm{CD}_{3} \mathrm{OD} 3.31$ p.p.m., except $\mathrm{CDCl}_{3}$ solutions were referenced to internal tetramethylsilane (TMS). The exact concentration of the compounds was determined by the quantitative NMR integration 'PULCON' experiment ${ }^{45}$. These settings were used for all PULCON experiments: relaxation delay of $30 \mathrm{~s}, 64 \mathrm{scans}, 2$ dummy scans, $90^{\circ}$ pulse and temperature at $298 \mathrm{~K}$.

Synthesis of 3-indole-(Leu-Imidazole)-arg (16). Cbz-Leu-5-methylimidazole ethyl ester $(0.24 \mathrm{~g}, 0.6 \mathrm{mmol})$ in $\mathrm{MeOH}(20 \mathrm{ml})$ was treated with $10 \% \mathrm{Pd} / \mathrm{C}(20 \mathrm{mg})$ and hydrogenated at $40 \mathrm{psi}$ on a Parr hydrogenator for $5 \mathrm{~h}$. The mixture was filtered through celite and the filtrate was concentrated in vacuo. The crude product was added to $\mathrm{N}$-Boc-indole-3-carboxylic acid $(0.20 \mathrm{~g}, 0.70 \mathrm{mmol})$, pre-activated (with

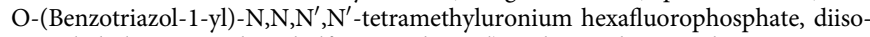
propylethylamine in dimethylformamide $2 \mathrm{ml}$ ) and stirred overnight at room temperature. The reaction mixture was diluted with ethyl acetate and washed with saturated $\mathrm{NaHCO}_{3}$. The organic extracts were dried over $\mathrm{MgSO}_{4}$, filtered and concentrated in vacuo. The crude product was dissolved in ethyl alcohol/ $\mathrm{H}_{2} \mathrm{O} / 2 \mathrm{M}$ $\mathrm{NaOH}(4: 1: 1,3 \mathrm{ml})$ and heated in a microwave at $120^{\circ} \mathrm{C}$ for $10 \mathrm{~min}$. The ethyl alcohol in the reaction was removed in vacuo and the aqueous solution was acidified with $2 \mathrm{M} \mathrm{HCl}$ and extracted with ethyl acetate. The combined organic extracts were dried over $\mathrm{MgSO}_{4}$, filtered and concentrated in vacuo. The crude product was coupled to H-Arg-OEt and then the ester was hydrolysed with $\mathrm{NaOH}$. The product was purified by rpHPLC and lyophilized to afford a white powder $(20 \mathrm{mg}, 7 \%) .{ }^{1} \mathrm{H}$ NMR $\left(600 \mathrm{MHz}, \mathrm{DMSO}-\mathrm{d}_{6}\right), \delta 8.25$ (br s, $\left.1 \mathrm{H}\right), 8.17$ (t, $J=3.0 \mathrm{~Hz}, 1 \mathrm{H}), 8.12(\mathrm{~d}, J=7.7 \mathrm{~Hz}, 1 \mathrm{H}), 8.02($ br s, $1 \mathrm{H}), 7.59$ (br s, $1 \mathrm{H}), 7.44(\mathrm{~d}$, $J=7.7 \mathrm{~Hz}, 1 \mathrm{H}), 7.15(\mathrm{t}, J=7.8 \mathrm{~Hz}, 1 \mathrm{H}), 7.10(\mathrm{t}, J=7.6 \mathrm{~Hz}, 1 \mathrm{H}), 5.36(\mathrm{~m}, 1 \mathrm{H}), 4.41$ $(\mathrm{m}, 1 \mathrm{H}), 3.17-3.08(\mathrm{~m}, 2 \mathrm{H}), 2.43(\mathrm{~s}, 3 \mathrm{H}), 1.96-1.82(\mathrm{~m}, 2 \mathrm{H}), 1.80-1.63(\mathrm{~m}, 3 \mathrm{H})$, 1.56-1.49 (m, 2H), 0.96-0.92 (two sets of d, $J=6.6 \mathrm{~Hz}, 6 \mathrm{H}) .{ }^{13} \mathrm{C}$ NMR $(150 \mathrm{MHz}$ DMSO- $\left.\mathrm{d}_{6}\right): \delta 173.3,164.5,158.7,158.5,158.3,156.6,136.3,128.7,126.3,122.0$, $120.9,120.5,111.9,51.2,44.5,42.0,40.3,28.5,25.3,24.4,22.8,21.6,10.5$. HRMS $(m / z):[\mathrm{MH}]^{+}$calcd for $\mathrm{C}_{25} \mathrm{H}_{35} \mathrm{~N}_{8} \mathrm{O}_{4}^{+}, 511.2776$; found, $511.2774 ; t_{\mathrm{R}}=7.9 \mathrm{~min}$ (0-100\% B in 10 min gradient).

Synthesis of 3-indole-(Leu-Ox)-arg (17). This compound was synthesized following the same procedure for compound 16, except that $\mathrm{H}-\mathrm{Leu}-\mathrm{Ox}-\mathrm{OMe}(0.11 \mathrm{~g}$ $0.46 \mathrm{mmol}$ ) was used for coupling to $\mathrm{N}$-Boc-indole-3-carboxylic acid and gave 17 $(27 \mathrm{mg}, 12 \%) .{ }^{1} \mathrm{H}$ NMR $\left(600 \mathrm{MHz}, \mathrm{DMSO}-\mathrm{d}_{6}\right): \delta 8.59(\mathrm{~s}, 1 \mathrm{H}), 8.39(\mathrm{~d}, J=8.6 \mathrm{~Hz}$, $1 \mathrm{H}), 8.22(\mathrm{~d}, J=8.6 \mathrm{~Hz}, 1 \mathrm{H}), 8.16(\mathrm{~d}, J=3.0 \mathrm{~Hz}, 1 \mathrm{H}), 8.11(\mathrm{~d}, J=7.9 \mathrm{~Hz}, 1 \mathrm{H})$, $7.55(\mathrm{t}, J=5.8 \mathrm{~Hz}, 1 \mathrm{H}), 7.43(\mathrm{~d}, J=8.2 \mathrm{~Hz}, 1 \mathrm{H}), 7.15(\mathrm{t}, J=7.4 \mathrm{~Hz}, 1 \mathrm{H}), 7.09$ $(\mathrm{t}, J=7.6 \mathrm{~Hz}, 1 \mathrm{H}), 5.36(\mathrm{~m}, 1 \mathrm{H}), 4.40(\mathrm{~m}, 1 \mathrm{H}), 3.14-3.06(\mathrm{~m}, 2 \mathrm{H}), 1.96(\mathrm{~m}, 1 \mathrm{H})$, $1.87(\mathrm{~m}, 1 \mathrm{H}), 1.83-1.75(\mathrm{~m}, 2 \mathrm{H}), 1.69(\mathrm{~m}, 1 \mathrm{H}), 1.56-1.45(\mathrm{~m}, 2 \mathrm{H}), 1.00-0.91$ (two sets of $\mathrm{d}, J=6.6 \mathrm{~Hz}, 6 \mathrm{H}) ;{ }^{13} \mathrm{C}$ NMR $\left(150 \mathrm{MHz}, \mathrm{DMSO}-\mathrm{d}_{6}\right): \delta 173.5,165.5,164.8$, $160.5,157.1,142.5,136.5,135.8,128.8,126.7,122.4,121.4,120.9,112.3,110.0,51.6$, 45.2, 41.7, 40.8, 28.3, 25.8, 24.7, 23.3, 21.9. HRMS $(\mathrm{m} / \mathrm{z}):[\mathrm{MH}]^{+}$calcd for $\mathrm{C}_{24} \mathrm{H}_{32} \mathrm{~N}_{7} \mathrm{O}_{5}^{+}$, 498.2459; found, 498.2461.; $t_{\mathrm{R}}=7.3 \mathrm{~min}(20-100 \%$ B in $10 \mathrm{~min}$ gradient)

Calculations of H-bond interaction energy. The geometry of the waterheterocycle H-bonded complex was optimized at the MP2/6-311 $++\mathrm{G}(3 \mathrm{~d}, 3 \mathrm{p})$ level using Gaussian 09. The H-bond interaction energy was the difference 
in energy of the complex from the sum of energies of water and heterocycle, calculated in isolation by the same method ${ }^{43}$.

Intracellular calcium release assay. HMDMs $\left(5 \times 10^{4}\right.$ cells per well) were added to a 96-well cleared-bottom black-wall assay plate (Corning) and incubated overnight at $37^{\circ} \mathrm{C}$. Before assay, the medium was removed and cells were incubated with dye-loading buffer (12 ml Hank's balance salt solution (HBSS) buffer, $4 \mu \mathrm{M}$ Fluo-3 AM, $25 \mu$ l Pluronic acid F-127 and $1 \%$ fetal bovine serum) for $1 \mathrm{~h}$ at $37^{\circ} \mathrm{C}$. Cells were then washed once with assay buffer (HBSS supplemented with $2.5 \mathrm{mM}$ probenecid and $20 \mathrm{mM}$ HEPES, pH 7.4). Compounds were dissolved in dimethyl sulphoxide (DMSO) to make a $10-\mathrm{mM}$ stock solution, then further diluted with HBSS buffer to the desired concentrations for intracellular calcium release assay. Fluorescence imaging plate reader was used to monitor intracellular release of $\mathrm{Ca}^{2+}$ via fluorescence measurement (excitation $495 \mathrm{~nm}$, emission $520 \mathrm{~nm}$ ) for $5 \mathrm{~min}$ after injection of agonists. Changes in fluorescence (\% response) were plotted against logarithmic concentrations of test compound. The $\mathrm{EC}_{50}$ values were derived from concentration response curves using nonlinear regression in Graphpad Prism v5.

125 I-C3a radioligand binding assay. Receptor binding was performed by ligand competition with $80 \mathrm{pM}\left[{ }^{125} \mathrm{I}\right]-\mathrm{C} 3 \mathrm{a}\left(2,200 \mathrm{Ci} \mathrm{mmol}^{-1}\right.$; Perkin Elmer, Torrance, CA, USA), HMDMs $\left(1.2 \times 10^{6}\right.$ cells ml $\left.{ }^{-1}\right), 80 \mathrm{pM}\left[{ }^{125} \mathrm{I}\right]-\mathrm{C} 3 \mathrm{a} \pm$ various concentrations of unlabelled $\mathrm{C} 3 \mathrm{a}$ or test agonist mixed with solvent $(50 \mathrm{mM}$ Tris, $3 \mathrm{mM} \mathrm{MgCl}_{2}, 0.1 \mathrm{mM} \mathrm{CaCl}_{2}, 0.5 \%$ (w/v) BSA, pH 7.4) for $60 \mathrm{~min}$ in a 96-well Nunc round-bottom plate at room temperature. Unbound $\left[{ }^{125} \mathrm{I}\right]-\mathrm{C} 3 \mathrm{a}$ was removed by filtration through glass microfibre filter GF/B (Whatman Iner. Ltd, England), which had been soaked in $0.6 \%$ polyethyleneimine to reduce nonspecific binding. The filter was washed three times with cold buffer ( $50 \mathrm{mM}$ Tris- $\mathrm{HCl}), \mathrm{pH} 7.4$, and bound $\left[{ }^{125} \mathrm{I}\right]-\mathrm{C} 3 \mathrm{a}$ was assessed by scintillation counting on Microbeta counter. Specific $\left[{ }^{125} \mathrm{I}\right]-\mathrm{C} 3 \mathrm{a}$ binding was defined as the difference between total binding and nonspecific binding as determined in the presence of $1 \mu \mathrm{M}$ unlabelled C3a. The $\mathrm{IC}_{50}$ value was derived from the concentration of agonist/antagonist required to inhibit $50 \%$ of $\left[{ }^{125} \mathrm{I}\right]-\mathrm{C} 3 \mathrm{a}$ binding.

Gene analysis. HMDMs were seeded at $1 \times 10^{6}$ per $\mathrm{ml}$ and allowed to adhere overnight. For inhibition experiments, HMDMs were pretreated with G $\alpha$ i inhibitor (200 $\mathrm{ng} \mathrm{ml}^{-1}$ pertussis toxin, overnight) or PLC $\beta$ inhibitor $(10 \mu \mathrm{M} \mathrm{U73122,}$ $30 \mathrm{~min})$, or C3aR antagonist (10 $\mathrm{M}$ SB290157, $30 \mathrm{~min})$, before adding C3a or 17 $(0.3 \mu \mathrm{M}, 30 \mathrm{~min})$. RNA was extracted from HMDMs according to ISOLATE II RNA Mini Kit (Bioline). Real-time PCR was measured on a ABI PRISM 7900HT instrument (Applied Biosystems), each target gene was normalized to housekeeping $18 \mathrm{~S}$ rRNA and fold change was calculated relative to untreated control. Primer sequence is shown in Supplementary Table S1.

Isolation of HMDMs. HMDMs were isolated using Ficoll-paque density centrifugation (GE Healthcare Bio-Science, Uppsala, Sweden) from buffy coat of anonymous human donors provided by the Australian Red Cross Blood Service, Brisbane. $\mathrm{CD} 14^{+}$monocytes were positively selected using CD14 ${ }^{+}$MACS magnetic beads (Miltenyi Biotech, Auburn, CA, USA) after successive magnetic sorting and washings. The $\mathrm{CD} 14^{+}$monocytes were then cultured at $37^{\circ} \mathrm{C}$ with $5 \%$ $\mathrm{CO}_{2}$ and differentiated to HMDMs using $100 \mathrm{ng} \mathrm{ml}^{-1}$ of recombinant human macrophage colony-stimulating factor (PeptroTech Inc., Rocky Hill, NJ, USA) at $1.5 \times 106$ cells per ml. HMDMs were kept in Iscove's modified Dulbecco's media supplemented with $10 \%$ fetal bovine serum, penicillin $\left(10 \mathrm{U} \mathrm{ml}^{-1}\right)$, streptomycin $\left(10 \mathrm{U} \mathrm{ml}^{-1}\right)$ and L-glutamine ( $2 \mathrm{mM}$; Invitrogen). HMDMs were supplemented after 5 days with fresh medium containing $100 \mathrm{ng} \mathrm{ml}^{-1}$ macrophage colony-stimulating factor. HMDMs were collected by gentle scraping in saline solution on day 7

$\boldsymbol{\beta}$-Hexosaminidase release assay. LAD2 human mast cells (kindly provided by Dr Dean Metcalfe, National Institute of Allergy and Infectious Diseases, National Institute of Health) were cultured as previously described ${ }^{46}$ and $\beta$-hexosaminidase release assay was performed as reported ${ }^{47}$. Briefly, LAD2 cells were presensitized with $\operatorname{IgE}\left(100 \mathrm{ng} \mathrm{ml}^{-1}\right)$ overnight before experiment. In the antagonist assay, SB290157 was pre-incubated for $30 \mathrm{~min}$ before the addition of C3a or 17, and release of $\beta$-hexosaminidase was measured at $405 \mathrm{~nm}$ using FLUOstar Optima (BMG LabTechnologies).

\section{References}

1. DeGrado, W. F., Summa, C. M., Pavone, V., Nastri, F. \& Lombardi, A. De novo design and structural characterization of proteins and metalloproteins. Annu. Rev. Biochem. 68, 779-819 (1999).

2. Stigers, K. D., Soth, M. J. \& Nowick, J. S. Designed molecules that fold to mimic protein secondary structures. Curr. Opin. Chem. Biol. 3, 714-723 (1999).

3. Venkatraman, J., Shankaramma, S. C. \& Balaram, P. Design of folded peptides. Chem. Rev. 101, 3131-3152 (2001).
4. Tyndall, J. D. A., Pfeiffer, B., Abbenante, G. \& Fairlie, D. P. Over one hundred peptide-activated $\mathrm{G}$ protein-coupled receptors recognize ligands with turn structure. Chem. Rev. 105, 793-826 (2005).

5. Seebach, D. \& Gardiner, J. Beta-peptidic peptidomimetics. Acc. Chem. Res. 41, 1366-1375 (2008).

6. Yin, H. \& Hamilton, A. D. Strategies for targeting protein-protein interactions with synthetic agents. Angew. Chem. Int. Ed. 44, 4130-4163 (2005).

7. Fairlie, D. P., West, M. L. \& Wong, A. K. Towards protein surface mimetics. Curr. Med. Chem. 5, 29-62 (1998).

8. Bullock, B. N., Jochim, A. L. \& Arora, P. S. Assessing helical protein interfaces for inhibitor design. J. Am. Chem. Soc. 133, 14220-14223 (2011).

9. Scholtz, J. M. \& Baldwin, R. L. The mechanism of alpha-helix formation by peptides. Annu. Rev. Biophys. Biomol. Struct. 21, 95-118 (1992).

10. Gerard, N. P. \& Gerard, C. Complement in allergy and asthma. Curr. Opin. Immunol. 14, 705-708 (2002).

11. Haas, P.-J. \& van, S. J. Anaphylatoxins: their role in bacterial infection and inflammation. Immunol. Res. 37, 161-175 (2007).

12. Hugli, T. E. Structure and function of the anaphylatoxins. Springer Semin. Immunopathol. 7, 193-219 (1984).

13. Masters, S. L., Simon, A., Aksentijevich, I. \& Kastner, D. L. Horror autoinflammaticus: the molecular pathophysiology of autoinflammatory disease. Annu. Rev. Immunol. 27, 621-668 (2009).

14. Zipfel, P. F. \& Skerka, C. Complement regulators and inhibitory proteins. Nat. Rev. Immunol. 9, 729-740 (2009).

15. Mizutani, N., Nabe, T. \& Yoshino, S. Complement C3a regulates late asthmatic response and airway hyperresponsiveness in mice. J. Immunol. 183, 4039-4046 (2009).

16. Hutamekalin, P. et al. Effect of the C3a-receptor antagonist SB 290157 on antiOVA polyclonal antibody-induced arthritis. J. Pharmacol. Sci. 112, 56-63 (2010).

17. Kildsgaard, J. et al. Cutting edge: targeted disruption of the C3a receptor gene demonstrates a novel protective anti-inflammatory role for $\mathrm{C} 3 \mathrm{a}$ in endotoxinshock. J. Immunol. 165, 5406-5409 (2000).

18. Jacob, A., Bao, L., Brorson, J., Quigg, R. J. \& Alexander, J. J. C3aR inhibition reduces neurodegeneration in experimental lupus. Lupus 19, 73-82 (2010).

19. Mamane, Y. et al. The C3a anaphylatoxin receptor is a key mediator of insulin resistance and functions by modulating adipose tissue macrophage infiltration and activation. Diabetes 58, 2006-2017 (2009).

20. Takematsu, H., Ohkohchi, K. \& Tagami, H. Demonstration of anaphylatoxins $\mathrm{C} 3 \mathrm{a}, \mathrm{C} 4 \mathrm{a}$ and $\mathrm{C} 5 \mathrm{a}$ in the scales of psoriasis and inflammatory pustular dermatoses. Br. J. Dermatol. 114, 1-6 (1986).

21. Tang, Z., Lu, B., Hatch, E., Sacks, S. H. \& Sheerin, N. S. C3a mediates epithelialto-mesenchymal transition in proteinuric nephropathy. J. Am. Soc. Nephrol. 20, 593-603 (2009).

22. Proctor, L. M. et al. Comparative anti-inflammatory activities of antagonists to $\mathrm{C} 3 \mathrm{a}$ and $\mathrm{C} 5 \mathrm{a}$ receptors in a rat model of intestinal ischaemia/reperfusion injury. Br. J. Pharmacol. 142, 756-764 (2004).

23. Lim, J. et al. C5aR and C3aR antagonists each inhibit diet-induced obesity, metabolic dysfunction, and adipocyte and macrophage signaling. FASEB J. 27, 822-831 (2013).

24. Pasupuleti, M. et al. Preservation of antimicrobial properties of complement peptide C3a, from invertebrates to humans. J. Biol. Chem. 282, 2520-2528 (2007).

25. Sonesson, A. et al. Antifungal activity of C3a and C3a-derived peptides against Candida. Biochim. Biophys. Acta Biomembr. 1768, 346-353 (2007).

26. Bokisch, V. A. \& Mullereb, H. j. Anaphylatoxin inactivator of human plasma its isolation and characterization as a carboxypeptidase. J. Clin. Invest. 49, 2427-2436 (1970).

27. Wilken, H. -C., Götze, O., Werfel, T. \& Zwirner, J. C3a(desArg) does not bind to and signal through the human C3a receptor. Immunol. Lett. 67, 141-145 (1999).

28. Scully, C. C. et al. Selective hexapeptide agonists and antagonists for human complement C3a receptor. J. Med. Chem. 53, 4938-4948 erratum 8208 (2010).

29. Ames, R. S. et al. Identification of a selective nonpeptide antagonist of the anaphylatoxin C3a receptor that demonstrates antiinflammatory activity in animal models. J. Immunol. 166, 6341-6348 (2001).

30. Denonne, F. et al. Discovery of new C3aR ligands. Part 2: amino-piperidine derivatives. Bioorg. Med. Chem. Lett. 17, 3262-3265 (2007).

31. Denonne, F. et al. Discovery of new C3aR ligands. Part 1: arginine derivatives. Bioorg. Med. Chem. Lett. 17, 3258-3261 (2007).

32. Grant, E. B. et al. Design, synthesis, and biological activity of diiminoisoindolines as complement component 3a antagonists. Bioorg. Med. Chem. Lett. 11, 2817-2820 (2001).

33. Ghassemian, A. et al. Efficient chemical synthesis of human complement protein C3a. Chem. Commun. 49, 2356-2358 (2013). 
34. Bajic, G., Yatime, L., Klos, A. \& Andersen, G. R. Human C3a and C3a desArg anaphylatoxins have conserved structures, in contrast to C5a and C5a desArg. Protein Sci. 22, 204-212 (2013).

35. Huber, R., Scholze, H., Paques, E. P. \& Deisenhofer, J. Crystal structure analysis and molecular model of human C3a anaphylatoxin. Hoppe Seylers Z. Physiol. Chem. 361, 1389-1399 (1980).

36. Hugli, T. E. \& Erickson, B. W. Synthetic peptides with the biological activities and specificity of human C3a anaphylatoxin. Proc. Natl Acad. Sci. USA 74, 1826-1830 (1977).

37. Ember, J. A. \& Hugli, T. E. Complement factors and their receptors. Immunopharmacology 38, 3-15 (1997).

38. Chao, T. H. et al. Role of the second extracellular loop of human C3a receptor in agonist binding and receptor function. J. Biol. Chem. 274, 9721-9728 (1999)

39. Fukuoka, Y., Ember, J. A. \& Hugli, T. E. Ligand binding sites on guinea pig C3aR: Point and deletion mutations in the large extracellular loop and vicinity. Biochem. Biophys. Res. Commun. 263, 357-360 (1999).

40. Sun, J. Z. et al. Identification of ligand effector binding sites in transmembrane regions of the human G protein-coupled C3a receptor. Protein Sci. 8, 2304-2311 (1999).

41. Wu, B. L. et al. Structures of the CXCR4 chemokine GPCR with small-molecule and cyclic peptide antagonists. Science 330, 1066-1071 (2010).

42. Ruiz-Gomez, G., Tyndall, J. D. A., Pfeiffer, B., Abbenante, G. \& Fairlie, D. P. Update 1 of: over one hundred peptide-activated $G$ protein-coupled receptors recognize ligands with turn structure. Chem. Rev. 110, PR1-PR41 (2010).

43. Frisch, M. J. et al. Gaussian 09, Revision A.02 (Gaussian Inc., Wallingford, CT, 2009).

44. Munkonda, M. N. et al. Recombinant acylation stimulating protein administration to $\mathrm{C} 3(-/-)$ mice increases insulin resistance via adipocyte inflammatory mechanisms. PLoS One 7, e46883 (2012).

45. Dreier, L. \& Wider, G. Concentration measurements by PULCON using X-filtered or 2D NMR spectra. Magn. Reson. Chem. 44, S206-S212 (2006).

46. Kirshenbaum, A. S. et al. Characterization of novel stem cell factor responsive human mast cell lines LAD 1 and 2 established from a patient with mast cell sarcoma/leukemia; activation following aggregation of FcepsilonRI or FcgammaRI. Leuk. Res. 27, 677-682 (2003).

47. Kuehn, H. S., Radinger, M. \& Gilfillan, A. M. Current Protocols in Immunology. (eds John, E. C. et al.) (Chapter 7, Unit 7, 38, 2010).

\section{Acknowledgements}

This study was supported by the Australian National Health and Medical Research Council through grants APP1000745, APP1028423 and an SPRF 1027369 fellowship to D.P.F., as well as by Australian Research Council grants DP130100629 and DP1093245, and a Federation fellowship (FF0668733) to D.P.F. and by the Queensland State Government (CIF grant)

\section{Author contributions}

R.C.R. and D.P.F. co-led the investigations, conceived the experiments, analysed the results and wrote the paper; R.C.R., M.-K.Y., A.N.R., P.C. and J.M.F. synthesized and characterized the compounds; R.S., M.-K.Y., J.K.H., J.Y.S., J.S.B. and J.L. performed the bioassays; M.J.S. conducted protein-ligand modelling; all authors contributed either materials, data and/or provided intellectual input, or helped interpret data.

\section{Additional information}

Supplementary Information accompanies this paper at http://www.nature.com/ naturecommunications

Competing financial interests: The authors are named on patent applications claiming C3aR agonists and antagonists owned by the University of Queensland ('Modulators of C3a Receptors' International Application No. PCT/AU2012/001364). There are no other competing interests.

Reprints and permission information is available online at http://npg.nature.com/ reprintsandpermissions/

How to cite this article: Reid, R. C. et al. Downsizing a human inflammatory protein to a small molecule with equal potency and functionality. Nat. Commun. 4:2802 doi: $10.1038 /$ ncomms3802 (2013). 